\title{
Inequality and Indignation
}

\section{Citation}

Cass R. Sunstein \& Edna Ullmann-Margalit, Inequality and Indignation (John M. Olin Program in Law \& Economics Working Paper No. 141, 2002).

\section{Published Version}

http://chicagounbound.uchicago.edu/law_and_economics/266/

\section{Permanent link}

http://nrs.harvard.edu/urn-3:HUL.InstRepos:12921751

\section{Terms of Use}

This article was downloaded from Harvard University's DASH repository, and is made available under the terms and conditions applicable to Other Posted Material, as set forth at http:// nrs.harvard.edu/urn-3:HUL.InstRepos:dash.current.terms-of-use\#LAA

\section{Share Your Story}

The Harvard community has made this article openly available.

Please share how this access benefits you. Submit a story.

\section{Accessibility}




\section{University of Chicago Law School Chicago Unbound}

Coase-Sandor Working Paper Series in Law and

Economics

Coase-Sandor Institute for Law and Economics

2002

\section{Inequality and Indignation}

Cass R. Sunstein

Edna Ullmann-Margalit

Follow this and additional works at: http://chicagounbound.uchicago.edu/law_and_economics Part of the Law Commons

\section{Recommended Citation}

Cass R. Sunstein \& Edna Ullmann-Margalit, "Inequality and Indignation" (John M. Olin Program in Law and Economics Working Paper No. 141, 2002).

This Working Paper is brought to you for free and open access by the Coase-Sandor Institute for Law and Economics at Chicago Unbound. It has been accepted for inclusion in Coase-Sandor Working Paper Series in Law and Economics by an authorized administrator of Chicago Unbound. For more information, please contact unbound@law.uchicago.edu. 


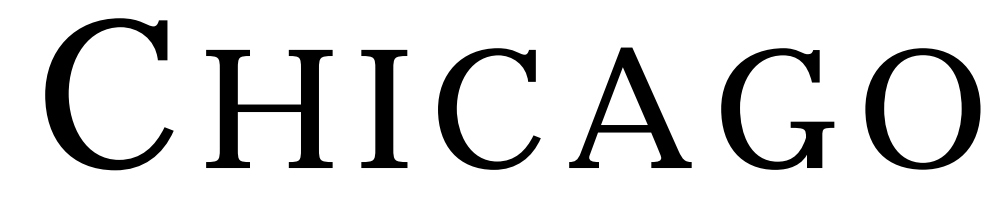

John M. Olin LAW \& ECONOMICS WORKING PAPER No. 141 (2D SERIES)

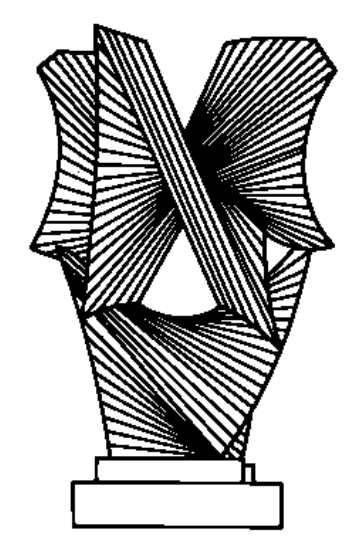

Inequality and Indignation

Edna Ullmann-Margalit and Cass R. Sunstein

\author{
THE LAW SCHOOL \\ THE UNIVERSITY OF CHICAGO
}

\begin{abstract}
This paper can be downloaded without charge at:
The Chicago Working Paper Series Index:

http://www.law.uchicago.edu/Lawecon/index.html
\end{abstract}

The Social Science Research Network Electronic Paper Collection:

http://papers.ssrn.com/paper.taf?abstract_id=301110 
Preliminary draft

$2 / 8 / 02$

\title{
Inequality and Indignation
}

\section{Edna Ullmann-Margalit* and Cass R. Sunstein ${ }^{* *}$}

\begin{abstract}
Inequalities often persist because both the advantaged and the disadvantaged stand to lose from change. Despite the probability of loss, moral indignation can lead the disadvantaged to seek to alter the status quo, by encouraging them to sacrifice their material self-interest for the sake of equality. Experimental research shows that moral indignation, understood as a willingness to suffer in order to punish unfair treatment by others, is widespread. It also indicates that a propensity to apparently self-defeating moral indignation can turn out to promote people's material self-interest, if and because others will anticipate their actions. But potential rebels face collective action problems. Some of these can be reduced through the acts of "indignation entrepreneurs," giving appropriate signals, organizing discussions by like-minded people, and engaging in acts of self-sacrifice. Law is relevant as well. By legitimating moral indignation and dissipating pluralistic ignorance, law can intensify and spread that indignation, thus increasing its expression. Alternatively, law can delegitimate moral indignation, or at least raise the cost of its expression, thus stabilizing a status quo of inequality. But the effects of law are unpredictable, in part because it will have moral authority for some but not for others; here too heterogeneity is an issue both for indignation entrepreneurs and their opponents. Examples are given from a range of areas, including labor-management relations, sexual harassment, civil rights, and domestic violence.
\end{abstract}

Every society contains countless inequalities. Some people have more money than others. Employers have authority over the livelihoods, and many daily decisions, of their workers. Some people are well educated, while others are not. In many nations, convicted felons are not allowed to vote. Many inequalities are found acceptable, but some produce indignation, which is a function of

* Professor of Philosophy at the Hebrew University of Jerusalem.

${ }^{*}$ Karl N. Llewellyn Distinguished Service Professor, Law School and Department of Political Science, University of Chicago. We are grateful to Avishai Margalit, Eric Posner, Richard Posner and Adrian Vermeule for valuable comments on a previous draft. 
perceived injustice. When inequalities do not seem unjust, they may be taken as unimportant, or else as natural, inevitable, responsive to "real differences" between groups, or in the interest of all sides.

In this Essay we use some simple tools from game theory and behavioral economics to cast light on the maintenance and disruption of unequal relationships. We emphasize that such relationships are often sustained for a simple reason: It would be harmful, to the disadvantaged as well as the advantaged, to alter the status quo, and both sides are aware of that fact. Consider an imaginable system of sexual hierarchy, in which women are systematically subordinate to men, but which is to the benefit of women as well as men in the sense that both sides would lose if the status quo were changed. Or consider a system of labor-management relations in which a rebellion by lowincome workers would lead to depressed wages or unemployment. Or consider a capitalist economy, pervaded by large inequalities but complying with Rawls' difference principle ${ }^{1}$ : however large, the inequalities are (by hypothesis) part of a system that promotes the welfare, suitably defined, of the least advantaged. In situations of this kind, unequal relationships tend to be stable and selfsustaining. Members of disadvantaged groups would suffer from a change, and they know it. Equally important, members of advantaged groups are aware of these facts and behave accordingly.

On reasonable assumptions, change seems quite impossible. What will nevertheless make it occur? As we shall show, change will result when the disadvantaged feel moral indignation, which will, under appropriate circumstances, lead them to disrupt an otherwise stable situation by sacrificing their material self-interest for the sake of increased equality. ${ }^{2}$ To clarify this point, we will take advantage of some striking empirical findings from behavioral economics. Moral indignation-a willingness to suffer material loss for the sake of ensuring fairer distributions - is widespread, and it turns out to be in people's strategic advantage if one condition is met: it is anticipated. Experiments show that when the disadvantaged are thought likely to sacrifice in order to punish perceived unfairness, the advantaged are willing to take steps to increase fairness - thus ensuring more egalitarian divisions. ${ }^{3}$

\footnotetext{
${ }^{1}$ See John Rawls, A Theory of Justice 75-80 (1971).

${ }^{2}$ For an early treatment of this problem from a different angle, see Edna Ullmann-Margalit, The Emergence of Norms (Oxford: Oxford University Pres, 1977).

${ }^{3}$ See Chaim Fershtman and Uri Gneezy, Discrimination in a Segmented Society: An Experimental Approach, Q J Econ 351 (2001).
} 
Of course moral indignation, and a willingness to act on it, will vary greatly across populations. As a result, rebels face some serious collective action problems. We show that "indignation entrepreneurs" help solve those problems by signaling the appropriateness of indignation and the importance of acting on it. We also show that law can help, above all by virtue of its expressive function. ${ }^{4}$ In exploring that expressive function, we emphasize four points. The first is that under circumstances of inequality, the reaction of the disadvantaged will not be uniform. Some people will be indignant, even outraged, and willing to act; others, while indignant, will be unwilling to incur the costs of rebellion; others will not be disturbed at all; others will be in between these various alternatives; and still others will be unsure about the appropriate attitude. The second point is that the beliefs and actions of members of disadvantaged groups will depend partly on the perceived beliefs and actions of other members. The third point is that different people will be willing to incur different costs for expressing moral indignation, partly but not only because of their uncertainty about whether an expression of indignation will be hopeless, in the long-run or the short-run. The fourth point is that in rebelling against inequality, members of disadvantaged groups face a collective action problem; some such members will be tempted to stay on the sidelines and to benefit from the rebellion of others. This problem is perhaps best solved through norms of solidarity by which indignation is brought to bear once more, in the form of moral pressure on free riders. ${ }^{5}$ Legal reform may be important here as well.

Political actors on both sides know that law may help on all four counts, partly through what it does and, no less important, partly through what it signals. Law may, for example, dissipate pluralistic ignorance, fuel and legitimate indignation, and offer some hope for change in the future. Consider laws forbidding the discharge of union members or criminalizing acts of domestic violence: even if infrequently enforced, such laws can both fuel indignation and make people more willing to act on it. For their part, advantaged groups may enlist the law to offer the opposite signals and to produce contrary effects. Consider laws banning

\footnotetext{
4 See Amy Wax, Expressive Law and Oppressive Norms, 86 Virginia Law Review 1731 (2000). We owe a general debt to Wax's treatment, which builds in turn on Ullmann-Margalit, supra note, as well as on Robert H. Frank, Passion within Reason: The Strategic Role of the Emotions (New York; Norton, 1988). Our current emphases, however, are different from those in these other discussions.

${ }^{5}$ On the willingness to punish free-riders, even at one's own expense, and on the associated emotion of anger, see Ernst Fehr and Simon Gachter, Altruistic Punishment in Humans, 415 Nature 137 (2002).
} 
union members from requiring workers to join unions as a condition of employment.

This essay comes in three parts. Part I shows why inequality is often stable and explains under what conditions people will rebel against it. Drawing on experimental evidence, Part II offers some remarks on moral indignation and spite and on the strategic aspects of the willingness to sacrifice material selfinterest for the sake of increased equality. Part III explores heterogeneity and the role of law. Here we move from the case of homogenous groups to that of heterogeneous groups, in which both moral indignation and the willingness to act on it are highly variable, and in which rebels face collective action problems. We explore in this connection the efforts of indignation entrepreneurs, the possibility of "indignation cascades," and the potential role of law, showing that even without much in the way of enforcement, law can embolden members of disadvantaged groups and strengthen their resolve. We also show that, conversely, law can shore up the status quo of inequality, either by suggesting that moral indignation is unjustified or by raising the cost of acting on it. But all of these possibilities depend on the moral authority of law, and there are significant social heterogeneities here as well. We discuss some of the dilemmas here for those seeking to use the law to transform the status quo or instead to entrench it. Part IV offers a brief conclusion.

\section{Inequality and Partiality}

Our starting point is the situation represented by the following array:

$(0 ; 0)(1 ; 2)$

figure 1

There are two equilibrium points here, the top-left corner and the bottom-right corner. As equilibrium points they are stable: once one of them is reached, no party gains by deviating from it alone. At the same time, the equilibrium states involve inequality, and symmetrically so: the value of the top-left box for Row Chooser is 2, as compared with 1 for Column Chooser, and the reverse holds for the bottom-right box. It is a matter of indifference at this initial stage whether the array is interpreted in terms of payoffs or of utilities; we shall have occasions below to note where it does make a difference. 
For purposes of analysis, we shall assume that rather than contemplating the 'game' represented by this array from the outside, the parties are already inside it, locked into one of its cells. Specifically, we shall assume that they are locked into the equilibrium that favors Row Chooser. The top-left cell, then, represents the status quo. We shall assume that while in the status quo, each party is aware of the larger picture. That is, each party is aware of the other three alternative states that could be reached were Row chooser, or Column Chooser, or both, to deviate from the status quo. In particular, they are both aware of the existence of an alternative, equilibrial status quo (represented by the bottom-right cell) in which their relative positions are reversed. This, as we shall see, bears on the strategic and manipulative aspects of the situation.

\section{A. Inequality Without Indignation}

From this simple description, and even with the stipulated information, it is not at all clear how the parties will perceive their situation. They might not see themselves in a conflict at all. Why? The answers are important because they shed light on the notion of indignation. Also, they help show how indignation might be stemmed when it starts to grow. There are several possibilities.

1. Negligible difference. While the status quo is asymmetrical between the two parties, both parties may regard the inequality as trivial, negligible, not worth fussing about.

This attitude toward the inequality may be highlighted if the array-now interpreted in terms of monetary payoffs-were, say, the following:

$(0 ; 0)(99 ; 100)$

figure 2

(Note that the gap between 99 and 100 is bridged by an "add 1" operation, whereas bridging the gap between 1 and 2 is ambiguous between the operations of "add 1" and "multiply by of 2. ")

In these circumstances, people are unlikely to protest or to rebel, simply because the stakes are so low. There is no occasion for indignation. Many kinds of inequalities are seen in these terms. In some situations the advantaged try to 
convince, or to manipulate, the disadvantaged to see the inequalities in these terms. ${ }^{6}$

2. Natural or otherwise real differences. The parties may think that the different payoffs are acceptable because they are a result of differences between them that are natural or otherwise real. Some people have unusual skills; they have benefited from the "natural lottery," not itself taken as morally objectionable.7 Biological differences might account for inequalities between men and women. Many in India accept the caste system as part of the natural order. An author of an untouchable autobiography writes that many untouchables "accept the notion of ritual impurity, the defining element of their own inferiority." And he adds, "Our fortunes, good or bad, were the will of God."

Even if differences are not natural, they might be taken to justify inequality. Famous basketball players and entertainers make far more money than janitors and secretaries, but perhaps the former have worked especially hard, or perhaps their relative wealth is justified in light of what they give to the millions of people who are willing to pay to see them. ${ }^{9}$ Inequalities might not seem so troubling if they are responsive to what are seen as real differences whose social consequences are not perceived in moral terms. Many people have, of course, argued for social and legal reform on the ground that morally irrelevant differences, whether or not natural, cannot justly be turned into sources of social disadvantage. ${ }^{10}$ These arguments can be taken as efforts to promote moral indignation when it would otherwise be absent.

3. Blind lottery. The inequality of the status quo, while not perceived by the parties as trivial or a defensible outgrowth of real differences, may be taken by

\footnotetext{
${ }^{6}$ We bracket here the question whether the absence of moral indignation, on this or other grounds, is a reflection of manipulation by the advantaged or instead "adaptive preferences," that is, preferences that have adapted to the status quo. See Jon Elster, Sour Grapes (Cambridge: Cambridge University Press, 1983).

${ }^{7}$ See John Rawls, A Theory of Justice 74 (1971). Rawls of course does challenge the justice of using the natural lottery as a basis for inequalities.

8 See Timur Kuran, Private Truths, Public Lies 198 (Cambridge: Harvard University Press, 1997).

${ }^{9}$ This is of course the topic of lively debate. See G.A. Cohen, If You're An Egalitarian, How Come You're So Rich? (Cambridge: Harvard University Press, 2000); Robert Nozick, Anarchy, State, and Utopia (1977).

${ }^{10}$ See, eg, John Stuart Mill, The Subjection of Women, in On Liberty and Other Essays 471 (John Gray ed. 1991); Martha Minow, Making All the Difference (Ithaca: Cornell University Press, 1993); Glenn Loury, The Anatomy of Racial Inequality (Cambridge: Harvard University Press, 2001).
} 
them to be a matter of luck. Among the farmers in a village, some turn out to have the better plots; friends go together on a vacation in a resort and only some receive rooms with a view; some people do well in a market and others do not, for the simple reason that one set of commodities turns out to be popular in the relevant period; some people are drafted for military service and others are not. The parties may be well aware that the asymmetry could, in an obvious sense, have been the reverse. Still, their attitude to it is more appropriately captured by "tough luck" or "too bad" than by "how unfair."

People perceive many real-life situations as if they result from blind lotteries, either natural or man-made. They often come to terms with the inequalities of their consequences, accept them and learn to live with them. Many disabled people, for example, come to see things in this way. ${ }^{11}$ But sometimes people do not find it easy to simply accept bad luck, and they become resentful. They may harbor ill feelings against the advantaged; they become bitter. Still, we take resentment as such to be free from moral underpinnings, and therefore to be kept distinct from indignation, which we take to have them. As we shall emphasize below, it is the indignant, not the resentful, who see the situation as unjust or morally wrong. ${ }^{12}$ Of course, resentment may, under certain conditions, turn into-or be manipulated into-indignation. ${ }^{13}$

4. Taking turns. The parties may acknowledge the inequality of the status quo and regard it as unfair-but not permanently or irremediably so. Rather than become indignant, they undertake to do something about it. The simplest and most natural way of doing something about it is to take turns. Given that the parties are aware of the larger picture, they may arrange to switch at some point to the alternative equilibrium state, the one represented by the bottom-right cell of the original payoff array. But note that they can only do it by acting in concert. No one party acting alone can achieve this switch.

It is worth recalling here that the original payoff array is in fact the one representing the well-known BoS game: the Battle of the Sexes (or: Ballet or

\footnotetext{
${ }^{11}$ See Melvin Lerner, The Belief in a Just World (New York: Plenum, 1980).

12 The distinction we are making here between indignation and resentment, while on the whole compatible with common usage, is stipulative. We bracket altogether well known philosophical uses of resentment (or 'resentiment') such as those made by Nietzsche, Sartre, Strawson, and others.

${ }^{13}$ For a series of case studies of this transformation, see Oppositional Consciousness (Jane Mansbridgeand Aldon Morris eds.) (Chicago: University of Chicago Press, 2001).
} 
Soccer? $\left.{ }^{14}\right)$. You enjoy it more when we go to the ballet; I enjoy it more when we go to a soccer match; but we both prefer to go together than to go alone. When the circumstances are right-a small number of participants, shared good will, and easy communication among them-then the parties may be motivated by the sentiments of fairness and reciprocity toward fixing the inequality inherent in their status quo. Such ideas as taking turns or switching roles are obvious solutions here. Within the family, strategies of this kind are familiar and have often been urged on equality grounds. ${ }^{15}$ Similar strategies have been suggested in the domain of political representation as well, with explicit reference to the notion of taking turns. ${ }^{16}$ Those who defend free markets sometimes argue that they produce a system, over time, of taking turns, with no entrenched inequalities, with widespread mobility, and with different people able to move toward the top of the social hierarchy. ${ }^{17}$ But of course here there is no explicit agreement between the parties to be taking turns: things just work out that way.

5. Mutual advantage. The parties may think that both of them gain from the situation, even if the two sides do not gain the same amount or in the same proportion. This may be the case when the disadvantaged see the present status quo as already an improvement, compared to a previous situation in which both parties were materially worse off (whether more equal or not). Workers may believe that their salaries, while far below those of managers, are made possible only by a cooperative arrangement from which, on the whole, they gain. Defenses of market economies, and challenges to legal efforts to increase equality within such economies, typically speak in terms of mutual advantage. ${ }^{18}$ Women may believe that they benefit less than men from a domestic arrangement, but that they still benefit, and that rebellion would be uncharitable, self-defeating, or worse.

Of course situations of this sort may not remain stable in the long run. This point helps underline an important general aspect of the situations we are here concerned with, which is their dynamic nature. Our arrays "freeze" a time slice, and enable us to focus on its characteristics. But we should not be misled by the game-theoretic analysis and think of it as static; these time slices have a before and an after. Indignation first builds up, then leads to an explosive

\footnotetext{
${ }^{14}$ Yet another playful alternative of this BoS game is 'Bach or Stravinsky?'. See Ariel Rubinstein, A Course in Game Theory, Cambridge, mass: MIT press, 1994, p. 15.

${ }_{15}$ See Susan Moller Okin, Justice, Gender, and the Family 170-86 (New York: Basic Books, 1989).

${ }^{16}$ See Lani Guinier, The Tyranny of the Majority (New York: The Free Press, 1997).

${ }^{17}$ See Seymour Martin Lipset, It Didn't Happen Here (1999).

${ }^{18}$ See e.g. Richard A. Epstein, In Defense of the Contract At Will, 51 U Chi L Rev 947 (1984).
} 
transformation, and the new situation that is regarded as a beneficial status quo of inequality today may breed indignation tomorrow. With time, the disadvantaged may come to focus on the indignity of their unequal situation rather than on the benefits it confers on them. We shall emphasize that if this does not come about spontaneously, rebels among the disadvantaged group may labor to stir up the feelings of the disadvantaged in this direction.

\section{B. Partiality and Disadvantage}

We now come to consider the case where the party disadvantaged by the inequality of the status quo (but not the other party) does experience this inequality as objectionable, or at least comes to experience it as such over time. To preface this discussion, let us note that it is not always clear who is advantaged and who is disadvantaged by any particular status quo. Sometimes both sides to an issue consider themselves the underdogs under existing, or proposed, arrangements and laws. People disagree, for example, about whether and to what extent modern societies reflect sex equality. An especially vivid example comes from the affirmative action controversy. Some opponents of affirmative action consider themselves to be the disadvantaged, and of course many advocates of affirmative action think the opposite. Because judgments of unfairness are systematically self-serving, this should not be entirely surprising. ${ }^{19}$ For our purposes, it is important to note that understandings of who is disadvantaged are not uniform within the population, can shift over time, and are even subject to manipulation.

Still, as familiar examples of the sorts of oppositions that we have in mind, consider the following: employees and employers, poor people and rich people within a single nation, people in poor nations and people in rich nations, handicapped and able-bodied, homosexuals and heterosexuals, AfricanAmericans and whites, Arab citizens and Jewish citizens of Israel, untouchables and upper-caste members in India, Catholics and Protestants in Northern Ireland. We posit that if the inequality of the situation persists over time, and is not acknowledged as such and remedied by the advantaged, then the situation may breed, in the disadvantaged, sentiments such as anger, outrage, jealousy, spite, envy, humiliation, and vengefulness.

\footnotetext{
${ }^{19}$ See Linda Babcock and George Loewenstein, Explaining Bargaining Impasse: The Role of SelfServing Biases, in Behavioral Law and Economics 255 (Cass R. Sunstein, ed.) (Cambridge: Cambrdge University Press, 2001).
} 
The term "indignation" is here designated to capture this constellation of sentiments. Understanding indignation as righteous anger produced by a sense of wrong to oneself and to others, we intend this term to signal a morally charged sentiment. This sentiment grows out of a felt insult to the dignity of the disadvantaged, which is sometimes perceived as humiliation. ${ }^{20}$ To flag the rise of the sentiment of moral indignation, we shall speak of the perceived partiality of the status quo, instead of using the more neutral "inequality." The status quo, then, is perceived here not as neutrally unequal but as morally wrong. ${ }^{21}$

To help isolate the point we want to make, let us focus now on the following array (call it the extreme-case partiality array):

$(0 ; 0)(0 ; 0)$

figure 3

This is not a coordination situation. There is here a single equilibrium point, ${ }^{22}$ namely the (unequal) status quo: it has no counterpart at the bottom-right corner. So the status quo appears, from the point of view of immediate self-interest, maximally robust: it looks like everyone's best choice in the situation. There is seemingly no credible threat for the disadvantaged to make, nothing strategically for them to gain but only to lose from deviating from the status quo. Those who rebel will sacrifice what little they have. And yet it is possible that even in this situation, rebellion will nonetheless occur. The reason is that if the inequality produces indignation, the disadvantaged may come to perceive the situation as one in which they have 'nothing to lose but their chains.' Of course they have something else to lose- the material payoff of the status quo-but by hypothesis, that material pay-off, though not worthless, is worth less to them than the cost of remaining in a situation of perceived injustice. Note that this analysis of the extreme-case partiality array begins by depicting it in terms of material payoffs rather than utilities. When indignation builds up, the disadvantaged derive disutility from the fact that they receive less than the advantaged. If we are now to "translate" this array to utilities, the upper-left cell would "translate", say, to $(2 ;-2)$ and the upper-right cell would perhaps become $(0 ; 2)$. The disparity between the two arrays helps explain the rebellion of the indignant.

\footnotetext{
${ }^{20}$ See Avishai Margalit, The Decent Society (Cambridge: Harvard University Press, 1997).

${ }^{21}$ See the treatment of the transformation of the Indian caste system in Kuran, supra note, at 32324.

${ }^{22}$ Or rather, only one strict equilibrium point. The bottom-right cell, with a payoff of $(0 ; 0)$, is a weak equilibrium: no one gains from deviating from it alone, but then no one loses either.
} 
What this means is that even though the status quo appears, from the point of view of material payoffs, strategically stable and robust, it might yet be vulnerable to what we might call a desperate rebellion. This rebellion, if it occurs, is driven by indignation, not by a belief that it will have strategic advantages, in the short run or the long run. This is so even when there is no alternative status quo that is attractive-in terms of absolute material position-to the presently disadvantaged. To the extent that the disadvantaged may come to prefer equality of (or in) misery to perpetual partiality, the threat exists that they will wish to drag the advantaged with them into the gutter (so to speak). Consider the possibility that workers will engage in strike activity, knowing that they might well lose as a result, but willing to face that risk because of moral indignation directed against what they perceive as an insufficiently equal division of profits with management. ${ }^{23}$ "Let my soul die with the Philistines," cried the Biblical Samson, choosing to bring down the roof and kill his Philistine captors along with himself, rather than to stay alive in captivity. ${ }^{24}$

\section{The Strategic Effects of Indignation}

Is it plausible to think that people will sacrifice their material self-interest for the sake of equality? Will this happen only under extreme and most extraordinary circumstances? Actually moral indignation frequently inclines people to sacrifice, by punishing, at their own expense, people who have behaved unfairly. ${ }^{25}$ This is a standard form of quasi-rationality. ${ }^{26}$ As we shall see, indignation may turn out to have strategic advantages, and in a way that bears directly on rebellion against partiality.

\section{A. Experimental Evidence}

To understand the operation of indignation, it is best to move from game theory to behavioral economics. Consider the results of the ultimatum game, a muchdiscussed test of the relationship between material self-interest and moral motivations, in the context of proposed distributions of resources between two

\footnotetext{
${ }^{23}$ See Michael Harper and Samuel Estreicher, Labor Law 94-97 (Boston: Aspen Law and Business, 1999).

${ }^{24}$ Judges, 16, 30.

${ }^{25}$ In the context of labor-management relations, where anticipated shirking by workers deters wage cuts, see Truman Bewley, Why Wages Don't Fall During A Recession (Cambridge: Harvard University Press, 2000); in the context of free riding, see Fehr and Gachter, supra note.

${ }^{26}$ See Richard Thaler, Quasi-Rational Economics (New York: Russell Sage, 1993).
} 
sides. ${ }^{27}$ In the ultimatum game, some subjects, called proposers, are asked to suggest a division of a certain sum of money between themselves and other subjects, called responders. Proposers might propose a division of 90/10, 80/20, $50 / 50-$ whatever they wish. But in this game, responders have a choice too: They can accept or reject the proposed division. If the responders agree to the proposal, players receive money in accordance with the allocation. If they say no, no one receives any money at all. Proposers are aware of this fact. No bargaining is allowed.

The standard economic prediction is that outcomes will be extremely unequalthat proposers will make offers approaching zero, and that responders will accept any positive offers. And if people care only about their material selfinterest, this is the set of results that should be observed. But the standard prediction badly fits the experimental data. ${ }^{28}$ Typically proposers propose a relatively equal division, with median proposals tending to be in the proportion of 60-40.29 Typically responders reject divisions that they perceive as highly unequal and therefore palpably unfair. Often they reject offers of less than 50-50. The ultimatum game is ordinarily played for small stakes, but the same pattern of results holds even when the stakes are quite large. The ultimatum game has been played for several weeks' or even months' salary in poor nations, and here too relatively equal decisions are proposed, and conspicuously unequal divisions are rejected..$^{30}$

All this is well known. But we want to draw attention to two less well-discussed features of these findings, both of which closely connect to our argument here. The first point is that responders are quite heterogeneous, in the sense that they will acquiesce with a diverse range of minimum offers. Only a small percentage of responders will accept an offer of 10-90 or less; most responders will not require a 50-50 split, though many do (typically about 35\%); some people will not agree to less than 30-70, whereas many others will set a 40-60 floor (typically

\footnotetext{
${ }^{27}$ For an overview, see Richard Thaler, The Ultimatum Game, in The Winner's Curse 21 (New York: The Free Press, 1992).

${ }^{28}$ See Christine Jolls et al., A Behavioral Approach to Law and Economics, 50 Stan. L. Rev. 1471, 1490 (1998).

${ }^{29}$ See id.

${ }^{30}$ See Colin Camerer and Richard Thaler, Ultimatums, Dictators, and Manners, 9 J Econ Pesp 209, 210-211 (1995); Vesna Prasnikar and Alvin Roth, Considerations of Fairness and Strategy, 107 Q J Eon 865, 873-75 (1992); Robert Slonim and Alvin Roth, Learning in High Stakes Ultimatum Games, 66 Econometrica 569, 573 (1998). Note that the last paper shows that when repetition is combined with very high stakes, offers decrease somewhat, though they remain far above the standard predictions. Id. at 573, 588 fig. 3A.
} 
about $60 \%) .{ }^{31}$ What does this mean? It means, first, that moral indignation itself, in the face of inequality, is variable; some people are offended by distributions that others find acceptable. It means, second, that spite, fueled by moral indignation, has a price, that it can be "bought," 32 and the necessary amount varies across individuals. These heterogeneities, and the existence of a price for spite, will bear on our discussion below. As we shall see, moral indignation, in the face of inequality, is generally variable, and people will vary in their willingness to incur costs for expressing it.

The second point is that those who feel moral indignation, and who are willing to sacrifice material self-interest in order to punish perceived unfairness, actually turn out to be at a strategic advantage, because they stand to receive more generous offers from materially self-interested proposers. Or to put it more precisely: Those who are perceived as prone to moral indignation, and as willing to sacrifice to punish what they see as unfairness, will receive more generous offers from self-interested proposers, thus producing more equal outcomes..$^{33}$ This point emerges from comparing the results of the ultimatum game with the results of a simple variation, the dictator game. ${ }^{34}$

In the dictator game, the proposer/dictator is allowed to impose any allocation she chooses; the responder/subject must accept that allocation. It turns out that in the dictator game, the median offer is significantly less egalitarian than in the ultimatum game. Still, even here divisions are not in the proportion of 99-1, but typically closer to $80-20 .{ }^{35}$ The far more equal allocation in the ultimatum game shows that the power of response matters a great deal, and that the anticipated

\footnotetext{
${ }^{31}$ See Jolls et al., supra note, at 1491-92; Werner Guth et al., An Experimental Analysis of Ultimatum Bargaining, 3 J Econ Behav. \& Org 367, 371-72, 375 tables 4 and 5; Daniel Kahneman et al., Fairness and the Assumptions of Economics, 59 J Bus S585, S291 tbl. 2. The most subtle test of people's willingness to trade off fairness and absolute income shows similar heterogeneities in both the United States and Spain. Gary Charness and Matthew Rabin, Understanding Social Preferences With Some Simple Tests (unpublished manuscript 2001)

32 See the model of fairness in Matthew Rabin, Incorporating Fairness into Game Theory and Economics, 83 Am Econ Rev 1281, 1282 (1993), showing that the willingness to act to punish unfairness will increase as the material cost of doing so decreases.

${ }^{33}$ Note that while they received more generous offers, they might not be better off. Someone who receives 40 out of 100, and is willing to accept that offering despite feeling some indignation that he did not receive 50, might be worse off than someone who receives 30 but feels no indignation at all.

${ }^{34}$ See, e.g., Camerer and Thaler, supra note, at 213-15; Alvin E. Roth, Bargaining Experiments in The Handbook of Experimental Economics 298-302 (John H. Kagel \& Alvin E. Roth eds.) (Princeton: Princeton University Press, 1995).

35 Id.
} 
moral indignation of responders is driving a significant amount of proposers' behavior in the ultimatum game. If rational proposers anticipate that responders will reject grossly unequal allocations, then proposers will propose more equal allocations, even if proposers are entirely self-interested. At this point the relationship to our concerns here should be clear: If advantaged people anticipate moral indignation from the disadvantaged, they should be expected to offer more equal divisions.

This last point has received its most direct empirical confirmation in a remarkable study in Israel, designed to test the effects of ethnicity in the ultimatum game. ${ }^{36}$ Israeli Jewish society consists largely of two main ethnic groups, Ashkenazim (European and American immigrants and their Israeli-born offspring) and Sephardim or Eastern Jews (Asian and African immigrants and their Israeli-born offspring). How, the experimenters asked, do Ashkenazi players treat Sephardi players? The answer is that they treat the Sephardim better than they treat fellow Ashkenazi players, not because they like them more, but because they believe that Eastern players are especially likely to reject offers perceived as unfair. In the dictator game, Sephardim and Ashkenazim received the same amount. ${ }^{37}$ But in the ultimatum game, Eastern players were offered significantly higher amounts-indeed, almost 50\% more than Ashkenazi players. In the authors' words: "There is ethnic discrimination in the ultimatum game. Eastern players receive larger transfers than Ashkenazi players. This discrimination is probably the outcome of a common ethnic stereotype in Israeli society, according to which men of Eastern origin are believed to react more harshly if treated unfairly." ${ }^{\prime 3}$ It is worth noting that in their capacity as responders, Eastern Israelis were not, in fact, more indignant and spiteful than Ashkenazi Israelis. The two groups did not differ in their willingness to accept unequal offers. The perception that led to more generous offers was not rooted in reality. But for purposes of ultimate outcomes it was the perception, not the reality, that mattered.

\footnotetext{
${ }^{36}$ Chaim Fershtman and Uri Gneezy, Discrimination in a Segmented Society: An Experimental Approach, Q J Econ 351 (2001).

${ }^{37} \mathrm{Id}$. at 365.

38 Id. at 369-70. A related interpretation of the findings couches them in terms of honor and humiliation rather than in terms injustice and unfairness. See Avishai Margalit, "A Just Peace or Just a Peace" (unpublished manuscript). The idea of indignation as here used covers perceived insults to honor as well as perceived injustice.
} 
To be sure, there is much debate about the sources of moral indignation in the ultimatum game. ${ }^{39}$ Some evidence suggests that relative position is importantthat some responders simply do not want to have less, or much less, than proposers. ${ }^{40}$ Other evidence suggests that responders greatly care about proposers' motivations-that if proposers are perceived behaving in a selfish way, many responders are willing to punish them..$^{41}$ This view is supported by the finding that people are far more willing to accept unequal offers if the experimenter constrains the proposers' choices, by, for example, saying that the proposer can only choose between 20-80 and 80-20; in these circumstances, 8020 is far more acceptable. ${ }^{42}$ There is also some evidence of cultural effects on outcomes. While members of all societies diverge from the standard economic prediction, the extent of the variation is culturally variable...$^{43}$ Our main focus here, however, is on the fact of indignation and its consequences for outcomes. We have seen that when people are indignant, they are liable to sacrifice material self-interest to promote what they see as increased fairness; and that when indignation is anticipated, and when it is backed by strategic ability to punish people in a position of power, those in that position will allow for more equal distributions.

\section{B. Generous Offers and Redistribution}

Let us move now from experiments to actual practice. In the face of moral indignation, the advantaged have a number of options. They can take steps to fend off a desperate rebellion, or indeed to anticipate and fend off any response like that of indignant responders in the ultimatum game. The advantaged might attempt to convince some or most of the disadvantaged that moral indignation is senseless - perhaps because inequalities are trivial, or work to the advantage of both sides, or respond to real differences, or are a part of a system of taking turns over time. All of these strategies are familiar in various contexts. But suppose

\footnotetext{
${ }^{39}$ For a good overview, see Gary Charness and Matthew Rabin, Understanding Social Preferences With Some Simple Tests (unpublished manuscript 2001).

${ }^{40}$ This is the interpretation in Robert Frank, Luxury Fever 116 (New York: The Free Press, 1998). See also Dirk Engelman and Martin Strobel, Inequality Aversion, Efficiency, and Maximin Preferences (unpublished manuscript 2001).

${ }^{41}$ Armin Falk et al., On the Nature of Fair Behavior, Ec. Inquiry (forthcoming). A more complex account emerges from Charness and Rabin, supra note.

42 See Falk et al., supra note.

${ }^{43}$ See the overview in Roth, supra note, at 282-88; Alvin Roth et al., Bargaining and Market Behavior in Jerusalem, Ljubljana, Pittsburgh, and Tokyo: An Experimental Study, 81 Am. Econ. Rev. 362 (1991).
} 
that these strategies do not work and that indignation proves robust. What might the advantaged do?

As distinct from the case of 'taking turns' discussed above, we assume here that those seeking to maintain the unequal status quo are not motivated by sentiments of fairness and reciprocity. We assume that they are akin to entirely self-interested proposers in the ultimatum game, seeking to perpetuate their privileges if they can. To the extent that they perceive the threat of a rebellion by the disadvantaged as real, they may consider appeasing them by reducing the inequality of the status quo. In other words, they may consider redistributionthe analogue to a more equal distribution in the ultimatum game.

For purposes of exposition and without changing anything of substance, take the extreme-case partiality array (figure 3 ) to reflect material payoffs, and suppose the numbers are the following:

figure 4

The advantaged may, for example, try to 'throw a bone' at the disadvantaged, so that the status quo will change into, say $(39 ; 21)$. Or they may offer a still more substantial redistribution by changing the status quo into, say, $(35,25)$. Will this suffice? The answer depends on the nature and extent of the moral indignation involved. It is imaginable that the disadvantaged will at this point stop seeing the inequality as partiality and possibly come to treat it along such lines as "negligible difference" or "mutual advantage." In the context of American labor law, relatively modest steps toward increasing union power have been thought both necessary and sufficient to secure industrial peace; the preamble to the National Labor Relations Act refers explicitly to the reduction of "industrial strife" as one of its purposes, ${ }^{44}$ a purpose that it has mostly achieved. It is possible, then, that an act of redistribution will defuse indignation, even if it does not provide equality. ${ }^{45}$ And might not the disadvantaged at this point consider that they already have something to lose by pushing further and taking the risk of losing everything? This is hardly unfamiliar; again consider the context of

\footnotetext{
${ }^{44}$ See Harper and Estreicher, supra note, at 101-02.

${ }^{45}$ See Stephen Holmes and Cass R. Sunstein, The Cost of Rights (New York: Norton, 1999) (discussing the provision of welfare, rather than equality, as part of a mutually beneficial deal among members of society).
} 
labor-management relations, where self-interested workers often settle for much less than they deem entirely fair. What, for that matter, are the conditions under which literal equality $(30 ; 30)$ will be offered, or reached? In the ultimatum game, over $1 \beta$ of responders insist on a 50-50 division ${ }^{46}$; in some circumstances, the disadvantaged will do the same. But is this the limit? Might there not be conditions under which, once the advantaged make concessions and are perceived as losing nerve, the dynamics will push things toward, say, (25;35) and even further?

These questions are empirical in nature: what will or might or is likely to happen, under differently specified conditions. They are also a bit abstract, because people are typically complaining about a particular dimension of inequality (race or sex discrimination, for example, or an absence of certain rights in the workplace, or poverty), and not arguing for equality in general, whatever that might mean. But the important point is the recognition of the potential role of the moral sentiments in posing a threat to the stability of an equilibrium state: even though the status quo is robust in game-theoretical terms, it is nevertheless liable to being overturned by a resentful underdog.

\section{Turning the tables}

Let us at this point reflect on partiality as related to our original array (figure 1). Recall that it was an inequitable, double-equilibrium coordination situation, as distinct from the extreme-case partiality array where the status quo is the single equilibrium state (figures 3,4 ). Here it is again:

The point we want to make is that if indignation was thought to make rebellion a possibility in the no-alternative-equilibrium situation, then here the status quo is even more vulnerable to rebellion. But how does the existence of an alternative equilibrium, in which the inequality between the parties is reversed, affect the situation?

The existence of an alternative equilibrium strengthens the threat to the stability of the status quo by making the threat strategic. To the extent that the threat of the disadvantaged to deviate from the status quo (from Column 1 to Column 2)

${ }^{46}$ See Jolls et al., supra note. 
is credible, it is to the benefit of the advantaged to deviate too (from Row 1 to Row 2). The reason, of course, is that if the advantaged do not deviate while the disadvantaged do, they end up in the state represented by the top-right cell, where everyone's payoff is 0 , whereas if they do deviate they end up in the alternative equilibrium state, represented by the bottom-right cell, where they manage to cut their losses, with a payoff of 1 , as against 2 to the formerlydisadvantaged. Thus, the strategic structure of the situation in effect forces the advantaged to acquiesce in a table turning maneuver, which makes them the newly disadvantaged. Examples come from professional sports within the United States. Athletes now receive substantial sums, often many millions each year, thus reducing profits and apparently ensuring, some of the time, that top athletes earn more than owners and high-level officers, even though the converse was true in earlier eras. The tables have thus been turned, but without leading owners and high-level officers to leave the business.

To be sure, when judged from the point of view of rational choice or game theory, the mere existence of the alternative equilibrium state, in itself, is not taken to constitute a strategic threat to the unequal status quo. After all, from that point of view it is contrary to the self-interest of the disadvantaged to deviate alone (reducing his payoff from 1 to 0 ) whether there exists an alternative equilibrium state or not. That is, from the game theoretical point of view it is irrational for the disadvantaged to deviate alone and risk losing everything. But what looks like an irrational move from the narrow perspective of the immediate self-interest comes to look like a credible threat when it is backed by the moral passion of indignation. Immediate psychological motives aroused by the moral sentiments turn out to augment, and at the same time to be backed by, a viable strategic threat. What we have here is passion in the service of reason. ${ }^{47}$

\section{Principle or Spite?}

Return to the array immediately above. As we have just noted, the threat of rebellion is augmented and made further credible by the existence of the alternative equilibrium state. But there is a further question: If the rebellion takes place and succeeds, and the alternative equilibrium is the new status quo, what exactly has been achieved? In the new status quo, the former disadvantaged are the newly advantaged, and we are once again in exactly the same sort of status

\footnotetext{
${ }^{47}$ Robert H. Frank, Passion within Reason: The Strategic Role of the Emotions (New York; Norton, 1988); see also Amy L. Wax, supra note.
} 
quo of inequality, with roles reversed. In theory, the analysis of the new situation is identical to the foregoing analysis of the initial one, though of course the history of table turning is likely to affect the attitudes of both parties in various ways. For example, the newly disadvantaged are perhaps more likely to suffer from resentment and indignation. Ethnic conflicts, with shifts in the categories of advantaged and disadvantaged, can sometimes be understood in these terms.

But a more intriguing question relates to a somewhat different situation. Consider the following array (call it the equitable alternative array):

figure 5

Everything we said just now, about the threat of rebellion being augmented and made further credible by the existence of the alternative equilibrium state, holds here too: the equitable bottom-right cell is a coordination equilibrium here too. Now suppose that in this new situation a rebellion takes place and succeeds and the alternative equilibrium is the new status quo. What exactly has been achieved here?

In the new status quo, the former disadvantaged have the same (material) payoff as before (namely, 1). So in the material sense they have gained nothing. The only difference is in the payoff to the advantaged, which now have 1 rather than the 2. With this shift, there is a problem about how to frame the point of the rebellion: Is the goal to achieve an equitable distribution, or instead to ensure that the advantaged are stripped of their privileges? The first may be seen as a noble principle, potentially with broad appeal; but the second might be seen as mere spite. Those seeking to perpetuate inequality often urge that there is no point (aside from envy) to moving from $(2 ; 1)$ to $(1 ; 1) .{ }^{48}$

${ }^{48}$ See the discussion of envy in John Rawls, A Theory of Justice 530-41 (Cambridge: Harvard University Press, 1971), which has spawned an extensive literature. See also Frank, Luxury Fever, supra note, for reasons to think that even apart from envy, $(2,1)$ may be worse than $(1,1)$, at least if these are understood in terms of payoffs rather than utilities. There is empirical evidence in support; consider the finding in Gary Charness and Matthew Rabin, Understanding Social Preferences With Some Simple Tests (unpublished manuscript 2001) that when asked to choose between 400 for self, 400 for stranger, and 400 for self, 750 for stranger, $31 \%$ of subjects choose 400,400 . Id. at 46 . 
At this point it might be well to identify some complications about the possible motivations of members of disadvantaged groups and about the nature of their indignation. Put in terms of utilities, the shift from $(2 ; 1)$ to $(1 ; 2)$ improves the absolute position of the disadvantaged, as well as their relative position. It does not, however, achieve equality. The shift from $(2 ; 1)$ to $(1 ; 1)$ improves the relative position of the disadvantaged and achieves equality, but does not improve their absolute position. People vary in what they care about most: absolute position, relative position, or equality. ${ }^{49}$ Which of the three do we assume the disadvantaged to be motivated by? The way we told the story, indignation is produced by inequality. But this in itself is not sufficient to disambiguate the situation and to tell us whether the disadvantaged in a status quo of inequality are motivated by a principled passion for equality as such, or simply by a desire to improve their position - whether absolute or relative.

To get a sense of the variety of permutations of the three motivations, consider other possible shifts from a status quo of inequality. A shift from $(2 ; 1)$ to $(5 ; 2)$ will be acceptable to the disadvantaged who only care about absolute utility ("As"), but rejected by the relative- utility minded ("Rs") as well as by those who care about equality as a matter of principle ("Es"). People who care only about relative position (Rs), so that their real goal is to do better than the relevant others, will welcome a shift from $(6,5)$ to $(1,3)$ : As and Es will reject this shift. For committed Es a shift from $(3,2)$ to $(1,1)$ would be readily accepted: here the commitment to equality is primary, even at the expense of absolute position. More pertinent to our concerns, a shift from $(2 ; 1)$ to $(1 ; 2)$ will please both As and Rs, but will be rejected by Es_-while the shift from $(2 ; 1)$ to $(1 ; 1)$ will be welcomed by both Es and Rs but a matter of indifference to the As.

In the cases that we are here emphasizing, the indignation-producing status quo of inequality was denoted by the canonical $(2 ; 1)$, and the shifts we considered were to $(1 ; 2)$ (in figure 1 ), to $(0 ; 0)$ (in figure 3 ), and to $(1 ; 1)$ (figure 5 ). We saw just now that pushing for these shifts may be variously motivated. Moreover, not only can we not tell the motives of the disadvantaged apart, but we also want to suggest that often the indignant themselves cannot tell them apart either. Or at least they cannot tell them apart at the initial stages of indignation and rebellion. Sometimes there is need to look to the subsequent social states in this evolving, dynamic situation, and to the observed behavior of the (formerly) disadvantaged in them, in order to clarify this question of motives. Thus: are these people content with the reversal from $(2 ; 1)$ to $(1 ; 2)$ ? Or do they push further, until $(1 ; 1)$

${ }^{49}$ For an intriguing demonstration, see id. 
or even $(0 ; 0)$ is achieved? From the answers to questions like these, the motives of the disadvantaged may be disentangled.

But the main point is that in all of the cases considered here, the shift cannot be achieved directly, in one move. In all of these cases, in order for the disadvantaged to achieve the desired shift they have to be lone deviators from the status quo, and thus they have to be willing to accept the state (at the upperright cell of all the arrays) of $(0 ; 0)$. Whatever else might happen next, this involves willingness on the part of the disadvantaged to sacrifice absolute position, a willingness to suffer-provided the advantaged suffer too. This willingness is the product of indignation. Whether the indignation is fueled solely by a passion for equality, or also by a desire to bring about the fall of the privileged, thereby improving relative position, may be impossible, or premature, to disentangle. And it may, ultimately, not really matter.

\section{Collective Action Problems and the Role of Law}

\section{A. Two strategic problems}

Thus far we have been writing as if there are only two players, understanding each of them to stand for a group as a whole. Of course this is a highly artificial way to see most real-world situations. There is no reason to expect group members who face a situation of inequality to agree in their reactions. Some may be indignant and others not at all; some may be willing to act on the basis of their indignation, while others are not; group members may not be able to, or want to, act in concert. ${ }^{50}$ Recall here the great diversity of responder behavior in the ultimatum game. To understand the relationship between inequality and indignation more precisely, and to see the possible role of law, it is important to recognize that if they seek to rebel, the disadvantaged potentially face, simultaneously, two types of strategic problems. Specifically, they may face both a coordination problem and a prisoner's dilemma-type (PD) problem.

1. Coordination problem and indignation entrepreneurs. In order for their rebellion to succeed and for the social change to take place, many or most of disadvantaged have to deviate from the status quo together. If only one member of a religious minority complains of discrimination, little is likely to happen in response. If we assume, as we have throughout, that the two 'players' here are groups of people

\footnotetext{
${ }^{50}$ See the various discussions in Oppositional Consciousness, supra note, and in particular AnnaMaria Marshall, A Spectrum in Oppositional Consciousness, in id. at 99, 111-13.
} 
(classes, population segments, and so forth) rather than two individuals, then obviously only if many act together do the disadvantaged have a chance to be effective. Of course it is likely to be the case that not everyone has to participate as long as a critical mass of participants is reached. But still the problem remains, of coordinating the deviating actions of a sufficient number of people to cross that threshold.

If this is a genuine coordination problem, the interests of the parties fully coincide. To solve the problem, the parties need explicit discussion and agreement, or proper signaling or (what comes to the same thing) saliency. In the situation we are addressing, one of the coordination equilibrium points (and there are by definition at least two) has to be salient somehow, or signaled somehow. A pervasive question for disadvantaged groups is how can a signal be given? The question is further compounded because the coordination problem in hand actually entails a series of sub-problems. There is the difficulty of agreeing on a shared understanding of the situation (is indignation the right response?), and then there is the difficulty of agreeing on a course of action (is it worthwhile to incur the potentially high costs of acting on the basis of indignation?).

There are various options here. An intriguing possibility involves the efforts of rebel leaders, who might be described for our purposes as "indignation entrepreneurs." As diverse but salient examples, consider Thomas Paine, Martin Luther King, Jr., Malcolm X, Yassir Arafat, Catharine MacKinnon, and Ward Connerly (influential opponent of affirmative action programs in California). The goal of indignation entrepreneurs is to convince people that indignation is morally appropriate and that the costs of expressing such indignation are worth incurring. ${ }^{51}$ The signals thus given may help to overcome the coordination problem. In providing those signals, indignation entrepreneurs sometimes take the special step of sacrificing themselves or (the extreme form of self-sacrifice) of becoming martyrs to the cause. ${ }^{52}$ Calling them martyrs, however, should not make us think that all such entrepreneurs deserve to be approved; there will always be those who will see them as manipulators or instigators. Here, as elsewhere, everything turns on one's evaluation of their ends and their means.

\footnotetext{
${ }^{51}$ See the analogous discussion of political entrepreneurs in the general category of extremism in Albert Breton and Silvana Dalmazzone, Information Control, Loss of Autonomy, and the Emergence of Political Extremism, in Political Extremism and Rationality 44, 57 (Albert Breton et al. eds.) (Cambridge: Cambridge University Press, 2002).

52 See Wax, supra, at 1744.
} 
A self-sacrificing leader, dedicated to the cause of the disadvantaged, might be among the first to rebel in defiance of the status quo. Consider, for example, the actions of Martin Luther King, Jr., seeking to promote civil disobedience and often emphasizing his own willingness (demonstrated in practice) to go to jail in response for his violations. King's frequent, highly publicized imprisonments represented a kind of martyrdom and hence produced a powerful signal, helping to solve the coordination problem by suggesting to thousands and even millions of people that civil disobedience would be justified and could be a widespread practice. If acts of this sort succeed in focusing attention on the cause of the disadvantaged, they may well ennoble that cause, fueling indignation. Moreover, they may in fact provide the signal for the entire group, encourage its members, and stir them to action. In the extreme case, the martyr's act can serve as a rallying point or battle cry for them to follow suit en masse. In this respect this sort of self-sacrifice and martyrdom functions as a coordinating device..$^{53}$

Indignation entrepreneurs also attempt to alter behavior by promoting discussion among like-minded members of disadvantaged groups, in an effort to inculcate emerging norms. ${ }^{54}$ This approach is likely to work: It is well established that when like-minded people speak with one another, they tend to end up believing a more extreme version of what they antecedently thought. ${ }^{55}$ If rebel leaders succeed in engaging members of disadvantaged groups in internal dialogue, and in isolating them within enclaves of group members, coordination will be much easier. Indignation and the willingness to act on it are highly likely to grow. ${ }^{56}$ People typically learn from the informational signals given by others, and it is easy to imagine "indignation cascades," in which B learns to be indignant because $\mathrm{A}$ is indignant, and $\mathrm{C}$ comes to share in the common

\footnotetext{
${ }^{53}$ See the general discussion in Dennis Chong, Collective Action and the Civil Rights Movement (Chicago: University of Chicago Press, 1991).

${ }^{54}$ See Brett C. Stockdill, Forging a Multidimensional Oppositional Consciousness, in Oppositional Consciousness, supra note, at 204, 22728.

${ }^{55}$ See Roger Brown, Social Psychology: The Second Edition (New York: The Free Press, 1986); Cass R. Sunstein, Designing Democracy ch. 1 (Oxford: Oxford University Press, 2001); Sharon Groch, Free Spaces: Creating Oppositional Consciousness in the Disability Rights Movement, in Oppositional Consciousness, supra note, at 65, 67-72; Cass R. Sunstein, Why They Hate Us: The Role of Social Dynamics, Harv. J. Law \& Pub. Policy (forthcoming 2002).

${ }^{56}$ For an emphasis on physicalsegregation and the rise of indignation, see Aldon Morris and Maomi Braine, Social Movements and Oppositional Consciousness, in Oppositional Consciousness, supra note, at 20, 29-30. Cf. Russell Hardin, The Crippled Epistemology of Extremism, in Political Rationality and Extremism, supra, at 7, 14-19 (discussing the effects of limited information on extremism).
} 
indignation of A and B, and D, E, and so forth go along. ${ }^{57}$ Reputational pressures also play a role, especially within groups of like-minded people. We shall return to these points presently.

\section{PD problem.}

(a) In general. At the same time that the disadvantaged, as a group, have to solve their coordination problem, they also have to worry about the possibility of free riders. This is a particular worry for indignation entrepreneurs, even for martyrs. In a sense, where there is a martyr everyone else is a free rider. The martyr to the cause is the only one who willingly incurs personal costs, while all the others enjoy the fruits of his or her self-sacrifice if it succeeds, and lose nothing if it fails. A martyr cannot do all that must be done; for a rebellion to succeed, those engaged in the activities that follow the martyr's sacrifice must solve the problem too. Assume, for example, that the rebellion requires certain acts - from verbal protests to civil disobedience - from which rebels might suffer. Because rebels face risks, everyone will be tempted not to join the rebellion but to remain on the sidelines. Of course moral indignation, spurring material self-sacrifice for the sake of equality, can overcome the temptation. And efforts to ensure discussion within enclaves, consisting of members of disadvantaged groups, can provide much help here. But we have emphasized that moral indignation will vary within the population of the disadvantaged, and also that the expression of moral indignation, for most people, has a price. Even when moral indignation is playing a significant social role, some people will refuse to join the rebellion.

If the critical mass of rebels is reached anyway, then the non-joiners stand to benefit from the success, and if it is not reached and the rebellion fails, then they do not pay the personal price (legal or other sanctions) that the rebels stand to pay. The strategic problem of overcoming this temptation, then, is the PD problem that the disadvantaged have to solve in order for their desired social change to take effect. The standard solutions to this problem come from social norms and through law. In the context we are discussing, law is not highly likely to be available, because rebels are not lawmakers. Still, rebels may be engaged in legal advocacy; below we offer some examples of the sorts of laws that they might urge. Also, law is made by coalitions, and in many circumstances the disadvantaged might be able to form coalitions with sympathetic groups within

\footnotetext{
${ }^{57}$ See the general treatment of informational cascades in David Hirshleifer, The Blind Leading the Blind, in The New Economics of Human Behavior 188 (Cambridge: Cambridge University Press, 1995).
} 
the broad class of the advantaged. In the United States, participants in the civil rights movement of the 1960s were able to obtain legal protection against discrimination in large part because they were able to enlist northern and western legislators to their cause. In any case - and this is our central point here - norms may have law-like functions.

(b) Reputational sanctions and second-order indignation. Without law, reputational sanctions are a good way of solving the coordination problem through a new form of moral indignation. Those who fail to participate in the rebellion might be subject to indignation as intense, in its way, as the moral indignation directed against the advantaged. If non-participants face ostracism or ridicule-if they are treated as traitors, cowards, scabs, or Uncle Toms-the PD problem might well be solved. And indeed, rebelling groups often take steps to impose sanctions on free riders. ${ }^{58}$ We can better understand those steps, and the intensity of the feelings that underlie them, if we see that they may be indispensable to collective success. Disadvantaged groups often develop strong norms of participation and solidarity, making deviation from the group's enterprise extremely costly for individuals. Such norms have often played a significant role in the labor movement. They can be found elsewhere as well, for apostates are often hated even more than infidels.

Here moral indignation is playing a double role. It is aimed against the advantaged group, but it is aimed, with equal or greater force, against fellow group members who free ride on the actions of rebels. Notice as well that it is important to inculcate not only moral indignation against free-riding members of the disadvantaged groups, but also a form of second-order indignation directed at those who do not express indignation against free-riders. Thus, for moral indignation to do its work here, an additional free-rider problem must be solved. ${ }^{59}$

(c) Indignation and its cost. For individual members of rebelling groups, however, there remain two problems: first, an assessment of whether it is appropriate to feel moral indignation and second, an evaluation of whether it is rational to act on the basis of moral indignation. We are assuming, that is, a stage in the rebellion when it is not at all clear whether moral indignation is sensible or

\footnotetext{
${ }^{58}$ See Laurence R. Iannaccone, Sacrifice and Stigma: Reducing Free-Riding in Cults, Communes, and Other Collectives, 100 J. Polit Economy 271 (1992); see also Fehr and Gachter, supra note, for empirical evidence of willingness of groups to punish free riders, even if the punishment is costly for the punishers.

59 This lesson can be drawn from Fehr and Gachter, supra note.
} 
appropriate, and when there is heterogeneity on that count within the affected group. Many members of the disadvantaged groups may remain skeptical or ambivalent. One reason is that they are likely to suffer from pluralistic ignorance: They do not know what others like them are thinking. If people's beliefs are a product of the perceived beliefs of others ("social proof"), this form of ignorance is a real disability. In order for the rebellion to succeed, much moral argument is needed on this count, alongside recruitment efforts, "consciousness-raising," and more. At the same time, pluralistic ignorance is also an opportunity for strategic actors. Members of disadvantaged groups will have an incentive to exaggerate the extent and intensity of moral indignation, whereas members of advantage groups will minimize both of them. Here too indignation entrepreneurs can play an important role, as can deliberative enclaves and indignation cascades discussed above.

Those who feel moral indignation will by hypothesis be willing to sacrifice their material self-interest to punish others; but how much indignation is required, and how much sacrifice will they make? Will they be willing to die for the cause? To put family members at risk? Here too we should expect a large degree of heterogeneity. For many people, incentives will matter even when moral indignation is real and significant.

\section{B. A Role for Law}

Both sides to the resulting conflicts are likely to want the law to be on their side, because of their interest in two key variables: moral indignation itself, which will vary within the population, and the willingness to act on it, which will also be highly variable, for some indignant people will prefer to suffer in silence. Of course the disadvantaged will want the law to legitimate their moral indignation and to decrease the cost of acting on it. The advantaged will want the law to do the opposite. Our emphasis here is on the possibility that laws, even ones that are little enforced, will have effects on norms and attitudes, so as to strengthen or to weaken indignation. We will also suggest that law, if enforced, can increase or decrease the cost of expressing indignation.

There are many complexities here. For the law to affect indignation, it will have to have a degree of moral authority. Typically the extent of its authority will vary across the population, often with asymmetries between members of advantaged and disadvantaged groups. And a legal rule may have the opposite of its intended effects, by, for example, spurring indignation when it is intended to defuse it. Whatever the law does, astute indignation entrepreneurs will use the 
law strategically. If it supports their efforts, they will invoke its moral authority to intensity indignation; if it attempts to entrench the status quo, they will claim that the very attempt is reason for intensified indignation and a testimonial to the rightness of their cause. For their part, supporters of the status quo will invoke the law to reduce indignation. This they will do either by urging that significant changes have been made in the interest of the disadvantaged, thus making indignation senseless, or by suggesting that if law directs itself against rebellion, its moral authority demonstrates that the rebellion is unjustified.

\section{(i) Transformative Law}

The disadvantaged, or at least the rebels within that group, would like the law to solve their free-rider problem. The rebels will also want the law to recognize the normative weight of their claim, to reduce partiality to some degree, and to fuel the view that the inequality of the status quo, or the equality-denying practice to which they object, is a form of injustice. Success in achieving these aims might give their struggle a vital boost. If the law carries moral authority, successful legal reform is liable to turn it from a mere brute power struggle to a push for change that is perceived as just and right. Under the right conditions, legal support can increase the likelihood that the threat to topple the status quo and upset existing arrangements will appear something other than a spiteful and irrational move against self-interest. If the law is on their side, then their struggle will likely be ennobled: legal sanction can make the rebellion appear not for personal gain but in order to vindicate principle. Consider the frequent pleas of Martin Luther King, Jr.: "If we are wrong, then the Constitution of the United States is wrong," and "All we are saying to America is, be true to what you said on paper."

But what might law do? The most obvious possibility is to outlaw a practice that contributes to inequality, not only providing sanctions against those who engage in that practice, but also in the process emboldening those who are rebelling against that practice. Consider civil rights laws in general, banning private discrimination in employment. The effects of these laws go well beyond their legal enforcement, whether public or private. If promotions and transfers are not allowed to reflect racial discrimination, people are more likely to object to discriminatory practices, merely because of the legal prohibition. ${ }^{60}$ These objections in turn have effects on behavior. By publicly advertising and affirming the rightness of the new convention, the law can increase the perception that an

\footnotetext{
${ }^{60}$ See the discussions in Oppositional Consciousness, supra note.
} 
existing practice is unjust, add momentum to private resentments, and provide a focal point around which players can rally and affirm their commitment to change. ${ }^{61}$

Or consider the effort to see sexual harassment as a civil rights violation. ${ }^{62}$ Before the civil rights law was understood to forbid sexual harassment, there was of course sexually harassing behavior. But there was no concept, or term, to stigmatize that behavior, which was seen, socially as well as legally, to be a private matter, not a pervasive practice that contributed to inequality. In these circumstances, it was not hardly possible to be indignant about the behavior; but indignation was far more difficult. A central effect of the new legal understanding is to give both advantaged and disadvantaged a morally charged vocabulary that embodies the belief that sexual harassment is indeed a reason for indignation. The expressive effect of the law continues to be important. Many of those who objected to sexual harassment, especially but not only in the early years, stood to lose a great deal from the objection. This was and is so partly because lawsuits are expensive and grueling, and partly because those who object to sexual harassment are not likely to improve their employment prospects as a result. Actual and anticipated indignation played, and plays, a crucial role in reducing the extent of the behavior. (Recall the ultimatum game, where proposers give better offers precisely because they anticipate indignation.) And because the law supports that indignation, people are all the more likely to be indignant.

In this way we can cast a new light on the contested idea that law has an expressive function ${ }^{63}$ - that law is important for what it says, independently of what it does. Sanctions, as well as costly enforcement, may not be necessary in order for the law to play a significant role in facilitating normative change. The expressive power of the law may well be sufficiently effective here. It may be effective, first, because it suggests that moral indignation is in fact appropriate. An important point here is that the very enactment of law will tend to dissipate pluralistic ignorance ${ }^{64}$ : If the political process has chosen to forbid certain conduct, this is a good signal that most people, and especially disadvantaged people, object to it.

\footnotetext{
${ }^{61}$ See Wax, supra note, at 1743.

${ }^{62}$ For a catalogue, see Anna-Maria Marshall, supra note, at 99-126.

${ }^{63}$ See Mathew Adler, Expressivist Theories of Law: A Skeptical Overview, 148 U Pa L Rev 1363 (2000)..

${ }^{64}$ See Richard McAdams, Norms Theory: An Attitudinal Theory of Expressive Law, 79 Oregon L. Rev. 339 (2000).
} 
The law may be effective, second, if and to the extent that it increases the benefits and decreases the costs of acting on the basis of moral indignation. If a civil action is available for victims of discrimination, the benefits of that form of rebellion are increased. It is well known that in certain circumstances, compliance with the law will occur even without enforcement of the law; one reason is that when conduct is against the law, private persons are emboldened to sanction violators. ${ }^{65}$ The same point holds for laws that forbid discriminatory practices. Whether or not the government acts to punish unlawful conduct, the legal rule is likely to stiffen the spines of those who might not otherwise act on the basis of their indignation.

Of course there are no guarantees here. The law might lack moral authority and hence the relevant expression may have little or no effect. ${ }^{66}$ In some areas of the United States it is not so important that the law forbids racial discrimination or sexual harassment. The relevant law is seen as an imposition from a kind of elite. The notion of "political correctness" has often been used to undermine the expressive effects of law founded on moral indignation; and one of the consequences of that notion has been to make people wonder whether moral indignation is in fact appropriate. Even if transformative law has moral authority, it might weaken the efforts of rebels, precisely because the legal reform, minor though it may be, may defuse moral indignation and encourage the disadvantaged to believe that the new status quo is acceptable. This effect has been observed with respect to what many see as modest gains, in the form of court decisions, from the women's movement in the United States. ${ }^{67}$

In short, the expressive effect of a transformative law cannot simply be read off the enactment. Such a law might be taken as a reason to stop a rebellion or instead as a reason to deepen and extend it. Indignation entrepreneurs will attempt to move social understandings in their preferred directions.

\footnotetext{
${ }^{65}$ See Robert Kagan and Jerome Skolnick, Banning Smoking: Compliance Without Enforcement, in Smoking Policy (Robert Rabin and Stephen Sugarman eds.) (New York: Oxford University

Press, 1993).

${ }^{66}$ See Dan Kahan, Gentle Nudges vs. Hard Shoves: Solving the Sticky Norms Problem, 67 U. Chi.

L. Rev 607 (2000).

${ }^{67}$ See Gerald Rosenberg, The Hollow Hope (Chicago: University of Chicago Press, 1991).
} 


\section{(ii) Entrenching Law}

For those who enjoy or otherwise support the inequality of the status quo, and seek to protect it against upheavals, law might not be necessary. Private sanctions and norms may be sufficient. Employers might be able to fire employees who seek a larger share of profits, or even to unionize. Civil rights workers might be beaten or at least ostracized. General norms against malcontents, or particular norms in favor of certain unequal practices, may do the work of law. There is of course the technique of naturalizing the status quo, of making it appear unthinkable that it could be otherwise. Social norms and conventions, often religious in nature, are recruited for this purpose. Thus the inferiority of women, of blacks, and of homosexuals has in many historical periods been made to seem designed by God or by nature. The class structure in feudal Europe and in England until not so long ago was augmented in similar ways.

Still, those seeking to protect the status quo may be expected to use the law for this purpose. They may, for example, seek legal authorization for the punitive steps taken against rebellion; they may also seek direct legal punishment of rebellion itself. As a prominent example, consider the effort to treat labor strikes as crimes or as subject to injunctions. ${ }^{68}$ In the same vein consider the early twentieth century effort to authorize employers to discharge members of labor unions, ${ }^{69}$ and the contemporary effort to enact "right to work" laws, which forbid unionized workforces from requiring new employees to join the union. ${ }^{70}$ If employers are allowed to discharge union members, and if the law recognizes that right, it might be harder, for some or many, to hold onto moral indignation against non-unionized firms: the law signals that indignation is misplaced. Or even if moral indignation is retained, the cost of expressing it has increased, as people may lose their jobs. Moreover, formal legal protections, backed by sanction, may be augmented by recourse to informal norms and conventions as well. In many workforces, at least in the United States, there are strong norms, encouraged by employers, in favor of rejecting unionization and union drives. One may expect walls of sanctions, both formal and informal, to be erected around the status quo. ${ }^{71}$

\footnotetext{
${ }^{68}$ See, e.g., Hitchman Coal \& Coke Co. v. Mitchell, 245 U.S. 229 (1917).

${ }^{69}$ See Coppage v. Kansas, 236 US 1 (1915).

70 See, e.g., Henderson and Estreicher, supra note, at 1070-1080.

${ }^{71}$ See Edna Ullmann-Margalit, supra note.
} 
The basic goal here is to change the incentive structure underlying the situation in such a way that deviation from the status quo becomes - or at any rate appears to become - prohibitively costly. The price should be such that the notion that 'I have nothing to lose but my chains' becomes insupportable. In communist Eastern Europe, for example, dissidents were deterred not just by increasing the penalties on them for any subversive activity, but also by threats to the welfare and educational prospects of their children.

In terms of our payoff array, the attempt is to effectively reduce the payoff for Column-Chooser's lone deviation from 0 to, say, -2 (if not much lower):

figure 6

Recall that the expression of moral indignation has a cost, for most people most of the time, even when moral indignation is intense. ${ }^{72}$ If the law sufficiently raises its cost, indignation is less likely to be expressed even when it exists. And when indignation is less often expressed, people who care about the beliefs and acts of others may silence themselves as well, potentially leading to a kind of spiral in favor of the status quo. ${ }^{73}$

But here too there are no guarantees. In fact there is an interesting alternative possibility: If the law is perceived as grossly unfair, the very fact of unfair punishment may increase moral indignation and make some people willing to act when they would otherwise decline to do so. Consider, as a case in point, the effort by the state of Colorado, in the mid-1990s, to forbid localities from outlawing discrimination on the basis of sexual orientation. ${ }^{74}$ By saying that localities could not treat that form of discrimination as a civil rights violation, Colorado was attempting to entrench a form of inequality. But did the effort actually serve to strengthen discriminatory norms, or did the opposite occur? There is no good evidence on the precise question. But it is clear that the law produced an intense public outcry on the part of advocates of gay rights. It is certainly plausible to think that the law actually strengthened moral indignation on the part of those who were inclined to object to discrimination on the ground

\footnotetext{
72 See the analogous discussion of fairness in Rabin, supra note.

${ }^{73}$ See the discussion of the movement from the unthinkable to the unthought in Timur Kuran, Private Truths, Public Lies 176-195 (Cambridge: Harvard University Press, 1997).

${ }^{74}$ The background is provided in Romer v. Evans, 517 U.S. 620 (1996), in which the Supreme Court struck down the state law.
} 
of sexual orientation. A similar point can be made with regard to laws that restrict the right to abortion. Just as transformative, or 'un-entrenching' law might weaken a rebel movement by reducing moral indignation, so an entrenching law might strengthen that movement, by increasing it.

\section{Conclusion}

Unequal relationships are often stable simply because it is in the material selfinterest of the less well off to maintain them. Change becomes possible if, as a result of moral indignation, people sacrifice their self-interest to produce change. As the experimental evidence suggests, it is not uncommon for people to show a willingness to lose materially in order to visit losses on those who seem to have been unfair. Real heterogeneity can be found, not only in the basic impulse, but also in diverse conceptions of when it is appropriate to be indignant, and in diverse judgments about how much can or should be sacrificed in order to express indignation. We have also seen that when advantaged people are aware that disadvantaged people are prone to express their indignation, even at their own expense, equality may be promoted as a result, simply because the advantaged ("proposers") will be prompted to fend off rebellion by offering more equal distributions. We have extended these points to cases involving large numbers of disadvantaged people with varying levels of moral indignation (ranging to none at all) and with willingness to incur varying costs to express it.

An ironic implication is that the more stable, strong, and immune to change the oppressive conventions and norms that protect a status quo of partiality may appear to be, the more vulnerable to change they may in fact be. This is so because under the right circumstances oppressive conventions are especially likely to breed indignation. And the more intense the indignation, the more credible the strategic threat of the oppressed to topple the status quo becomes. At this stage effective coordination among the disadvantaged may be sufficient to produce significant change. In helping to bring about such coordination, indignation entrepreneurs are likely to have an important role.

Law can be important both in assisting and in preventing the rebellion. Law affects the two crucial variables: the extent of moral indignation and the costs of expressing it. If the law allows or requires equality-abridging practices, members of the disadvantaged group may be more likely to see those practices as natural, or as an outgrowth of real differences or as otherwise justified. If the law bans equality-abridging practices, more people are likely to be indignant about them, partly because of the moral authority of law, partly because the law can decrease 
the costs or increase the benefits of objecting to those practices. Both the phenomenon of "compliance without enforcement" and that of "increased equality without rebellion" can be better understood in this light.

By virtue of its expressive power, law can lend legitimacy to the moral indignation and hence increase the credibility of the threat to upset the status quo. Law can also play a pivotal role in providing a rallying point and thus in functioning as a coordination device for the disadvantaged. At the same time, law is contested terrain. The advantaged will press for legal initiatives that will give moral support to the status quo and raise the cost of acting on the basis of indignation. But legal victories on either side might turn out counterproductive. Such victories might demobilize rebels, suggesting that indignation is no longer appropriate. At the same time, legal repression may increase indignation, thus aggravating the very problem that the advantaged seek to solve. When moral indignation is on the rise, both sides, seeking to enlist the expressive power of the law, face some recurring dilemmas.

Readers with comments should address them to:

Cass R. Sunstein

Karl N. Llewellyn Distinguished Service Professor of Jurisprudence University of Chicago Law School

1111 East 60th Street

Chicago, IL 60637

csunstei@midway.uchicago.edu 


\section{Chicago Working Papers in Law and Economics}

(Second Series)

1. William M. Landes, Copyright Protection of Letters, Diaries and Other Unpublished Works: An Economic Approach (July 1991).

2. Richard A. Epstein, The Path to The T. J. Hooper: The Theory and History of Custom in the Law of Tort (August 1991).

3. Cass R. Sunstein, On Property and Constitutionalism (September 1991).

4. Richard A. Posner, Blackmail, Privacy, and Freedom of Contract (February 1992).

5. Randal C. Picker, Security Interests, Misbehavior, and Common Pools (February 1992).

6. Tomas J. Philipson \& Richard A. Posner, Optimal Regulation of AIDS (April 1992).

7. Douglas G. Baird, Revisiting Auctions in Chapter 11 (April 1992).

8. William M. Landes, Sequential versus Unitary Trials: An Economic Analysis (July 1992).

9. William M. Landes \& Richard A. Posner, The Influence of Economics on Law: A Quantitative Study (August 1992).

10. Alan O. Sykes, The Welfare Economics of Immigration Law: A Theoretical Survey With An Analysis of U.S. Policy (September 1992).

11. Douglas G. Baird, 1992 Katz Lecture: Reconstructing Contracts (November 1992).

12. Gary S. Becker, The Economic Way of Looking at Life (January 1993).

13. J. Mark Ramseyer, Credibly Committing to Efficiency Wages: Cotton Spinning Cartels in Imperial Japan (March 1993).

14. Cass R. Sunstein, Endogenous Preferences, Environmental Law (April 1993).

15. Richard A. Posner, What Do Judges and Justices Maximize? (The Same Thing Everyone Else Does) (April 1993).

16. Lucian Arye Bebchuk and Randal C. Picker, Bankruptcy Rules, Managerial Entrenchment, and Firm-Specific Human Capital (August 1993).

17. J. Mark Ramseyer, Explicit Reasons for Implicit Contracts: The Legal Logic to the Japanese Main Bank System (August 1993).

18. William M. Landes and Richard A. Posner, The Economics of Anticipatory Adjudication (September 1993).

19. Kenneth W. Dam, The Economic Underpinnings of Patent Law (September 1993).

20. Alan O. Sykes, An Introduction to Regression Analysis (October 1993).

21. Richard A. Epstein, The Ubiquity of the Benefit Principle (March 1994).

22. Randal C. Picker, An Introduction to Game Theory and the Law (June 1994).

23. William M. Landes, Counterclaims: An Economic Analysis (June 1994).

24. J. Mark Ramseyer, The Market for Children: Evidence from Early Modern Japan (August 1994).

25. Robert H. Gertner and Geoffrey P. Miller, Settlement Escrows (August 1994).

26. Kenneth W. Dam, Some Economic Considerations in the Intellectual Property Protection of Software (August 1994).

27. Cass R. Sunstein, Rules and Rulelessness, (October 1994). 
28. David Friedman, More Justice for Less Money: A Step Beyond Cimino (December 1994).

29. Daniel Shaviro, Budget Deficits and the Intergenerational Distribution of Lifetime Consumption (January 1995).

30. Douglas G. Baird, The Law and Economics of Contract Damages (February 1995).

31. Daniel Kessler, Thomas Meites, and Geoffrey P. Miller, Explaining Deviations from the Fifty Percent Rule: A Multimodal Approach to the Selection of Cases for Litigation (March 1995).

32. Geoffrey P. Miller, Das Kapital: Solvency Regulation of the American Business Enterprise (April 1995).

33. Richard Craswell, Freedom of Contract (August 1995).

34. J. Mark Ramseyer, Public Choice (November 1995).

35. Kenneth W. Dam, Intellectual Property in an Age of Software and Biotechnology (November 1995).

36. Cass R. Sunstein, Social Norms and Social Roles (January 1996).

37. J. Mark Ramseyer and Eric B. Rasmusen, Judicial Independence in Civil Law Regimes: Econometrics from Japan (January 1996).

38. Richard A. Epstein, Transaction Costs and Property Rights: Or Do Good Fences Make Good Neighbors? (March 1996).

39. Cass R. Sunstein, The Cost-Benefit State (May 1996).

40. William M. Landes and Richard A. Posner, The Economics of Legal Disputes Over the Ownership of Works of Art and Other Collectibles (July 1996).

41. John R. Lott, Jr. and David B. Mustard, Crime, Deterrence, and Right-to-Carry Concealed Handguns (August 1996).

42. Cass R. Sunstein, Health-Health Tradeoffs (September 1996).

43. G. Baird, The Hidden Virtues of Chapter 11: An Overview of the Law and Economics of Financially Distressed Firms (March 1997).

44. Richard A. Posner, Community, Wealth, and Equality (March 1997).

45. William M. Landes, The Art of Law and Economics: An Autobiographical Essay (March 1997).

46. Cass R. Sunstein, Behavioral Analysis of Law (April 1997).

47. John R. Lott, Jr. and Kermit Daniel, Term Limits and Electoral Competitiveness: Evidence from California's State Legislative Races (May 1997).

48. Randal C. Picker, Simple Games in a Complex World: A Generative Approach to the Adoption of Norms (June 1997).

49. Richard A. Epstein, Contracts Small and Contracts Large: Contract Law through the Lens of Laissez-Faire (August 1997).

50. Cass R. Sunstein, Daniel Kahneman, and David Schkade, Assessing Punitive Damages (with Notes on Cognition and Valuation in Law) (December 1997).

51. William M. Landes, Lawrence Lessig, and Michael E. Solimine, Judicial Influence: A Citation Analysis of Federal Courts of Appeals Judges (January 1998).

52. John R. Lott, Jr., A Simple Explanation for Why Campaign Expenditures are Increasing: The Government is Getting Bigger (February 1998). 
53. Richard A. Posner, Values and Consequences: An Introduction to Economic Analysis of Law (March 1998).

54. Denise DiPasquale and Edward L. Glaeser, Incentives and Social Capital: Are Homeowners Better Citizens? (April 1998).

55. Christine Jolls, Cass R. Sunstein, and Richard Thaler, A Behavioral Approach to Law and Economics (May 1998).

56. John R. Lott, Jr., Does a Helping Hand Put Others At Risk?: Affirmative Action, Police Departments, and Crime (May 1998).

57. Cass R. Sunstein and Edna Ullmann-Margalit, Second-Order Decisions (June 1998).

58. Jonathan M. Karpoff and John R. Lott, Jr., Punitive Damages: Their Determinants, Effects on Firm Value, and the Impact of Supreme Court and Congressional Attempts to Limit Awards (July 1998).

59. Kenneth W. Dam, Self-Help in the Digital Jungle (August 1998).

60. John R. Lott, Jr., How Dramatically Did Women's Suffrage Change the Size and Scope of Government? (September 1998)

61. Kevin A. Kordana and Eric A. Posner, A Positive Theory of Chapter 11 (October 1998)

62. David A. Weisbach, Line Drawing, Doctrine, and Efficiency in the Tax Law (November 1998)

63. Jack L. Goldsmith and Eric A. Posner, A Theory of Customary International Law (November 1998)

64. John R. Lott, Jr., Public Schooling, Indoctrination, and Totalitarianism (December 1998)

65. Cass R. Sunstein, Private Broadcasters and the Public Interest: Notes Toward A "Third Way" (January 1999)

66. Richard A. Posner, An Economic Approach to the Law of Evidence (February 1999)

67. Yannis Bakos, Erik Brynjolfsson, Douglas Lichtman, Shared Information Goods (February 1999)

68. Kenneth W. Dam, Intellectual Property and the Academic Enterprise (February 1999)

69. Gertrud M. Fremling and Richard A. Posner, Status Signaling and the Law, with Particular Application to Sexual Harassment (March 1999)

70. Cass R. Sunstein, Must Formalism Be Defended Empirically? (March 1999)

71. Jonathan M. Karpoff, John R. Lott, Jr., and Graeme Rankine, Environmental Violations, Legal Penalties, and Reputation Costs (March 1999)

72. Matthew D. Adler and Eric A. Posner, Rethinking Cost-Benefit Analysis (April 1999)

73. John R. Lott, Jr. and William M. Landes, Multiple Victim Public Shooting, Bombings, and Right-to-Carry Concealed Handgun Laws: Contrasting Private and Public Law Enforcement (April 1999) 
74. Lisa Bernstein, The Questionable Empirical Basis of Article 2's Incorporation Strategy: A Preliminary Study (May 1999)

75. Richard A. Epstein, Deconstructing Privacy: and Putting It Back Together Again (May 1999)

76. William M. Landes, Winning the Art Lottery: The Economic Returns to the Ganz Collection (May 1999)

77. Cass R. Sunstein, David Schkade, and Daniel Kahneman, Do People Want Optimal Deterrence? (June 1999)

78. Tomas J. Philipson and Richard A. Posner, The Long-Run Growth in Obesity as a Function of Technological Change (June 1999)

79. David A. Weisbach, Ironing Out the Flat Tax (August 1999)

80. Eric A. Posner, A Theory of Contract Law under Conditions of Radical Judicial Error (August 1999)

81. David Schkade, Cass R. Sunstein, and Daniel Kahneman, Are Juries Less Erratic than Individuals? Deliberation, Polarization, and Punitive Damages (September 1999)

82. Cass R. Sunstein, Nondelegation Canons (September 1999)

83. Richard A. Posner, The Theory and Practice of Citations Analysis, with Special Reference to Law and Economics (September 1999)

84. Randal C. Picker, Regulating Network Industries: A Look at Intel (October 1999)

85. Cass R. Sunstein, Cognition and Cost-Benefit Analysis (October 1999)

86. Douglas G. Baird and Edward R. Morrison, Optimal Timing and Legal Decisionmaking: The Case of the Liquidation Decision in Bankruptcy (October 1999)

87. Gertrud M. Fremling and Richard A. Posner, Market Signaling of Personal Characteristics (November 1999)

88. Matthew D. Adler and Eric A. Posner, Implementing Cost-Benefit Analysis When Preferences Are Distorted (November 1999)

89. Richard A. Posner, Orwell versus Huxley: Economics, Technology, Privacy, and Satire (November 1999)

90. David A. Weisbach, Should the Tax Law Require Current Accrual of Interest on Derivative Financial Instruments? (December 1999)

91. Cass R. Sunstein, The Law of Group Polarization (December 1999)

92. Eric A. Posner, Agency Models in Law and Economics (January 2000)

93. Karen Eggleston, Eric A. Posner, and Richard Zeckhauser, Simplicity and Complexity in Contracts (January 2000)

94. Douglas G. Baird and Robert K. Rasmussen, Boyd's Legacy and Blackstone's Ghost (February 2000)

95. David Schkade, Cass R. Sunstein, Daniel Kahneman, Deliberating about Dollars: The Severity Shift (February 2000)

96. Richard A. Posner and Eric B. Rasmusen, Creating and Enforcing Norms, with Special Reference to Sanctions (March 2000) 
97. Douglas Lichtman, Property Rights in Emerging Platform Technologies (April 2000)

98. Cass R. Sunstein and Edna Ullmann-Margalit, Solidarity in Consumption (May 2000)

99. David A. Weisbach, An Economic Analysis of Anti-Tax Avoidance Laws (May 2000)

100. Cass R. Sunstein, Human Behavior and the Law of Work (June 2000)

101. William M. Landes and Richard A. Posner, Harmless Error (June 2000)

102. Robert H. Frank and Cass R. Sunstein, Cost-Benefit Analysis and Relative Position (August 2000)

103. Eric A. Posner, Law and the Emotions (September 2000)

104. Cass R. Sunstein, Cost-Benefit Default Principles (October 2000)

105. Jack Goldsmith and Alan Sykes, The Dormant Commerce Clause and the Internet (November 2000)

106. Richard A. Posner, Antitrust in the New Economy (November 2000)

107. Douglas Lichtman, Scott Baker, and Kate Kraus, Strategic Disclosure in the Patent System (November 2000)

108. Jack L. Goldsmith and Eric A. Posner, Moral and Legal Rhetoric in International Relations: A Rational Choice Perspective (November 2000)

109. William Meadow and Cass R. Sunstein, Statistics, Not Experts (December 2000)

110. Saul Levmore, Conjunction and Aggregation (December 2000)

111. Saul Levmore, Puzzling Stock Options and Compensation Norms (December 2000)

112. Richard A. Epstein and Alan O. Sykes, The Assault on Managed Care: Vicarious Liability, Class Actions and the Patient's Bill of Rights (December 2000)

113. William M. Landes, Copyright, Borrowed Images and Appropriation Art: An Economic Approach (December 2000)

114. Cass R. Sunstein, Switching the Default Rule (January 2001)

115. George G. Triantis, Financial Contract Design in the World of Venture Capital (January 2001)

116. Jack Goldsmith, Statutory Foreign Affairs Preemption (February 2001)

117. Richard Hynes and Eric A. Posner, The Law and Economics of Consumer Finance (February 2001)

118. Cass R. Sunstein, Academic Fads and Fashions (with Special Reference to Law) (March 2001)

119. Eric A. Posner, Controlling Agencies with Cost-Benefit Analysis: A Positive Political Theory Perspective (April 2001)

120. Douglas G. Baird, Does Bogart Still Get Scale? Rights of Publicity in the Digital Age (April 2001)

121. Douglas G. Baird and Robert K. Rasmussen, Control Rights, Priority Rights and the Conceptual Foundations of Corporate Reorganization (April 2001)

122. David A. Weisbach, Ten Truths about Tax Shelters (May 2001) 
123. William M. Landes, What Has the Visual Arts Rights Act of 1990 Accomplished? (May 2001)

124. Cass R. Sunstein, Social and Economic Rights? Lessons from South Africa (May 2001)

125. Christopher Avery, Christine Jolls, Richard A. Posner, and Alvin E. Roth, The Market for Federal Judicial Law Clerks (June 2001)

126. Douglas G. Baird and Edward R. Morrison, Bankruptcy Decision Making (June 2001)

127. Cass R. Sunstein, Regulating Risks after ATA (June 2001)

128. Cass R. Sunstein, The Laws of Fear (June 2001)

129. Richard A. Epstein, In and Out of Public Solution: The Hidden Perils of Property Transfer (July 2001)

130. Randal C. Picker, Pursuing a Remedy in Microsoft: The Declining Need for Centralized Coordination in a Networked World (July 2001)

131. Cass R. Sunstein, Daniel Kahneman, David Schkade, and Ilana Ritov, Predictably Incoherent Judgments (July 2001)

132. Eric A. Posner, Courts Should Not Enforce Government Contracts (August 2001)

133. Lisa Bernstein, Private Commercial Law in the Cotton Industry: Creating Cooperation through Rules, Norms, and Institutions (August 2001)

134. Richard A. Epstein, The Allocation of the Commons:Parking and Stopping on the Commons (August 2001)

135. Cass R. Sunstein, The Arithmetic of Arsenic (September 2001)

136. Eric A. Posner, Richard Hynes, and Anup Malani, The Political Economy of Property Exemption Laws (September 2001)

137. Eric A. Posner and George G. Triantis, Covenants Not to Compete from an Incomplete Contracts Perspective (September 2001)

138. Cass R. Sunstein, Probability Neglect: Emptions, Worst Cases, and Law (November 2001)

139. Randall S. Kroszner and Philip E. Strahan, Throwing Good Money after Bad? Board Connections and Conflicts in Bank Lending (December 2001)

140. Alan O. Sykes, TRIPs, Pharmaceuticals, Developing Countries, and the Doha "Solution" (February 2002)

141. Edna Ull;mann-Margalit and Cass R. Sunstein, Inequality and Indignation (February 2002) 